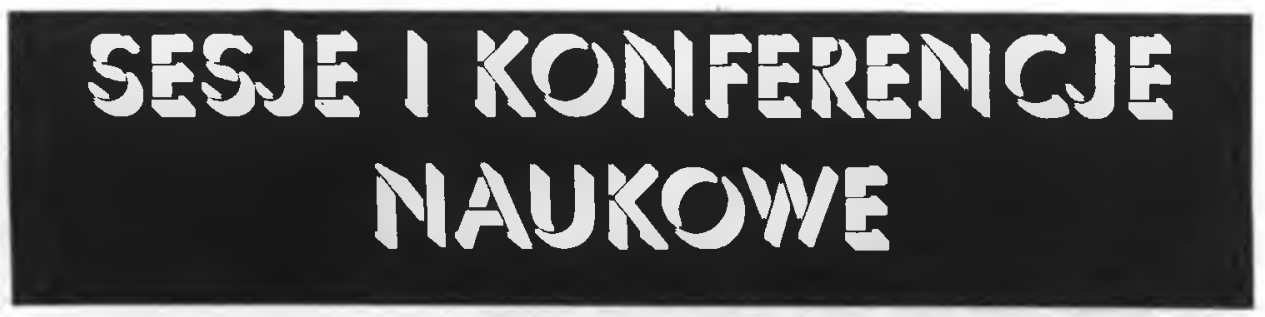

\title{
Sprawozdania
}

\section{Jubileuszowy Międzynarodowy Kongres Historyków Wychowania (Leuven-Kortrijk, Belgia 15-18.08.1998)}

Zaplanowany w ub. roku w Dublinie w Irlandii kolejny 20-ty już miẹdzynarodowy kongres historyków wychowania zorganizowany przez International Standing Conference for the History of Education (ISCHE) odbył się w filii Katolickiego Uniwersytetu Leuven w Kortjik w Belgii w dniach $15-18.08 .1998$ r.

Władze międzynarodowej organizacji historyków wychowania (egzekutywa ISCHE) wybierają ostatnio bardzo szerokie i pojemne zakresy tematyki obrad. Toteż kongres w Kortrijk obradował wokól tematu: Imagine, all the Education. The Visual in the Making of the Education Space through History.

Odbywały się obrady plenarne oraz posiedzenie 16 kongresowych grup roboczych, a także trzech stałych grup roboczych (standing working group - SWG) afiliowanych przy ISCHE. Czwarta SWG zajmująca się dziejami wychowania przedszkolnego $w$ tym roku nie obradowała.

W pierwszym dniu odbyło się otwarcie kongresu, którego dokonali: prof. dr M. Joniau, rektor Katolickiego Uniwersytetu w Leuven, prof. dr J. Dekker obecny prezydent ISCHE (z Uniwersytetu Groningen w Holandii) i prof. dr M. Depaepe lokalny organizator ISCHE XX (z Uniwersytetu w Leuven). Wszyscy wygłosili adresy powitalne do ponad 200 uczestników z 25 krajów świata, ze wszystkich kontynentów (Argentyny, Australii, Belgii, Brazylii, Danii, Finlandii, Holandii, Hiszpanii, Irlandii, Izraela, Japonii, Kanady, Meksyku, Norwegii, Polski, Portugalii, Republiki Federalnej Niemiec, Republiki Południowej Afryki, Rosji, Szwajcarii, Szwecji, Stanów Zjednoczonych, Weggier, Wielkiej Brytanii, Włoch).

Referat plenarny ilustrowany przeźroczami pt: Ways of saying, ways of seeing: Public images of Teachers (19th - 20th century) wygłosił prof. dr Antonio Novoa z Uniwersytetu w Lizbonie (Portugalia).

Po przerwie odbyły się zebrania w 19 grupach roboczych. Debatowały one nad następującymi problemami: Some Visual Aspects of Education in the Antiqity, Middle Ages and Early Modern Times (I); Images and Metaphors in Educational Ideas, Theories, Mentalities (II); The Use of Media in New Educational Movements (III); Architecture and Education (IV); Creating Educational Space (V); The Visual in/as Education (VI; Images and Contents of Textbooks (VII); Popular Media and Educational technologies (VIII); Educational Emblems (IX); Education in Cartoons 
and Strips (X); Pictures andPhotography in/over Education (XI); Movies and Film in/over Education (XII); Visual records in Education and Education Museums (XIII); Educational Press and Media (XIV); Visual Aides in (Re) constructiong History (XV); Education Visoins for the Future (XVI); The Enlightenment Idea of Human Rights in Philosophy and Education Postmodern (XVII); History of Education as a Teaching Subject and Field of Research (XVIII) Gendered Images (XIX).

W godzinach wieczornych miało miejsce zwiedzanie miasta Kortrijk, gdyż campus Kulak filii Katolickiego Uniwersytetu w Leuven znajduje się $3 \mathrm{~km}$ poza miastem. Pod koniec dnia uczestnicy zostali przyjęci przez mera miasta $w$ miejscowym ratuszu.

Drugi dzień (16 sierpnia) poświęcony byl prawie w całości obradom w tematycznych grupach roboczych. Wygłoszono referaty oraz prowadzono intensywne dyskusje.

W godzinach popołudniowych odbył się wyjazd autobusami do miasta Ypres na znane tereny flandryjskich pól bitewnych z czasów I wojny światowej. Zwiedzono także muzeum I wojny światowej oraz muzeum dziejów szkolnictwa.

W miejscowym teatrze odbył się wykład plenarny prof. dra Reinharda Stacha z Uniwersytetu w Duisburgu (RFN), dydaktyka zaproszonego przez organizatorów.

W trzecim dniu (17 sierpnia) kontynuowane były obrady w grupach roboczych.

W godzinach popołudniowych odbyła się wizyta w głównej siedzibie Katolickiego Uniwersytetu w Leuven.

Po zwiedzeniu miasta w auli promocyjnej uniwersytetu odbył się wykład plenarny zamówiony przez organizatorów pt.: The Fascinating World of the „Affixiones”, or the Visual Thermatization of Education in Classical Jezuit Teaching, wygłoszony $\mathrm{i}$ ilustrowany przezroczami przez prof. dra K. Portemana (z Katolickiego Uniwersytetu w Leuven).

Dzien trzeci został zakończony uroczystością jubileuszową obchodów 20-lecia ISCHE. Prof. M. Depaepe przedstawil dzieje organizacji od pierwszego kongresu $w$ Belgii $w$ Leuven, zapoczątkowanego przez prof. dra Mauritiusa de Vroede, który był pierwszym prezydentem. Dalsze kongresy wiodły przez Polskę (Jabłonna 1980), Francję (1981), Węgry (1982), Wielką Brytanię (1983), Republikę Federalną Niemiec (1984), Hiszpanię (1985), Włochy (1986), Wegry (1987), Finlandię (1988), Norwegię (1989), Czechoslowację (1990), Szwajcarię (1991), Portugalię (1993), Holandię (1994), Hiszpanię (1995), Polskę (Kraków 1996), Irlandię (1997) i Belgię (1998).

Dzieje ISCHE zostały również przedstawione na specjalnie wykonanym i zaprezentowanym uczestnikom filmie (dla ilustracji dwóch kongresów w Polsce wybrano wyjątkowo mało ciekawe materiały).

Następnie wygłoszono adresy gratulacyjne i wręczono pamiątkowe upominki twórcy ISCHE, emerytowanemu obecnie prof. drowi M. de Vroede (Katolicki Uniwersytet w Leuven), prof. drowi Czesławowi Majorkowi WSP - Kraków, który był współzałożycielem ISCHE, organizatorem XVIII Kongresu w Krakowie i uczestnikiem wszystkich dwudziestu kongresów. Był to miły akcent dla Polski i obecnych Polaków. Upominek otrzymał także prof. Olav Sunnano (Uniwersytet w Oslo), który byl obecny podczas dziewiętnastu kongresów.

W tym dniu odbyło się także posiedzenie plename ISCHE. Poświęcone było ono głównie przygotowaniu XXI Kongresu, który odbędzie się w 1999 r. w Sydney (Australia); publikacjom ISCHE oraz 19-nastemu Międzynarodowemu Kongresowi Nauk Historycznych, który odbędzie się pod patronatem ISCHE w 2000 r. w Oslo i obradować będzie na temat „The uses and misuses of gender in the history of education".

W czwartym dniu obrad (18 sierpnia) kontynuowano prace grup roboczych oraz miał miejsce wykład plenarny pt.: The Home as Educational Space: Bayonne Housing and the Architecture of Working Class Childhood, 1917 -1939 przygotowany i wygłoszony przez dr Terese Richardson z Uniwersytetu Południowej Florydy w Tampie (USA). Odbyła się także plenarna sesja zamykająca obrady. 
W XX jubileuszowym kongresie historyków wychowania w Kortrijk, jak zwykle aktywny udział brali Polacy: Bogusław Chmielowski (Akademia Wychowania Fizycznego w Katowicach), Jan Hellwig (UAM - Poznań i WSEH - Skierniewice), Czesław Majorek (WSP - Kraków), Lech Mokrzecki i Józef Żerko (UG).

Jan Hellwig

\section{Ogólnopolski Zjazd Pedagogiczny}

(Poznań 21 - 23 września 1998)

W dniach 21 - 23 września 1998 r. odbył się w Poznaniu III Ogólnopolski Zjazd Pedagogiczny jako część obchodów 150-lecia Polskiego Towarzystwa Pedagogicznego w Poznaniu, założonego przez Ewarysta Estkowskiego. Nawiązał on do tradycji spotkań pedagogów polskich, zainicjowanej przez I Zjazd Pedagogów Polskich w Rembertowie pod Warszawą w 1993 roku. Tematem przewodnim obrad była „Pedagogika i edukacja wobec nadziei i zagrożeń współczesności”.

Uroczystego otwarcia obrad dokonał Jego Magnificencja Rektor UAM, prof. dr hab. Stefan Jurga. Wygłosił on słowo wstępne oraz odczytał okolicznościowe adresy wojewody poznańskiego Macieja Musiała, profesorów Wincentego Okonia, Stefana Woloszyna i Leszka Kuźnickiego, prezesa Polskiej Akademii Nauk.

Pierwszy dzień obrad plenarnych przebiegał pod hasłem: „Edukacja wobec nadziei i zagrożeń wspólczesności”. Z referatami wystąpili: prof. Zbigniew Kwieciński, który wskazał na kryzys kultury i tożsamości, na fakt utraty znaczenia tradycyjnych wartości na rzecz agresywnych zachowań docierających do odbiorców kultury za pośrednictwem środków masowego przekazu i na nasilający się kryzys szkoły we wszystkich jej przejawach oraz prof. Tadeusz Lewowicki, który zwrócił uwagę na słabą liczebność kadry naukowej i na rosnącą lukę pokoleniową, przy jednoczesnym dynamicznym wzroście liczby uczelni (głównie niepaństwowych). Zaapelował również o podjęcie intensywnych badań nad nowymi metodami przygotowania nauczycieli.

Uwieńczeniem obrad plenarnych pierwszego dnia Zjazdu była dyskusja panelowa przebiegająca pod hasłem "Przełom stuleci - alternatywy przyszłości - wyzwania dla edukacji”. Prof. Lech Witkowski zwrócił uwage na schorzenia cywilizacyjne w zakresie konsumpcji dóbr kultury: anoreksję i bulimię. Bulimia edukacyjna wyraża się zdaniem referenta w powszechnym stosowaniu zasady "zakuć, zdać, zapomnieć". Z kolei prof. Wojciech Gasparski postawil postulat likwidacji funkcjonalnego analfabetyzmu w Polsce poprzez ukierunkowanie nauczania na przekazywanie wiedzy, wychowywanie oraz na wywoływanie $i$ wzmacnianie naturalnego głodu wiedzy ucznia. W. Gasparski zauważył także, iż konieczne jest wytworzenie postawy pozytywnej wobec konieczności ciągłego uczenia się. Prof. Andrzej Mencwel poruszył zagadnienie Paidei jako wzorca kulturowego. Jego zdaniem jednym z najważniejszych zadań stojących przed pedagogiką jest podnoszenie godności istoty ludzkiej. Za prawdziwego człowieka może uważać się jedynie istota potrafiąca współczuć, wspaniałomyślna, szlachetna. Realizująca się $w$ ideale humanitas. Kolejnym mówcą był prof. Józef Lipiec, który zajął się roważaniami nad miejscem pedagogiki we współczesnej nauce. Edukacja jest procesem o niskim poziomie sterowalności, co wynika, zdaniem prelegenta, z faktu, iż 